\title{
Management Of Missing Person's Properties In Maqasid Syariah Dimension
}

\author{
Sulaiman M.A ${ }^{a^{*}}$, Wan Yusoff W.Z $Z^{b}$, Al-Edrus S.M.D ${ }^{b}$, Shafie. $F^{a}$ \\ aDepartment of Real Estate Management, Faculty of Technology Management and Business, Universiti Tun Hussein Onn Malaysia (UTHM), \\ Parit Raja, 86400 Batu Pahat, Johor Darul Takzim, Malaysia \\ ${ }^{b}$ De Institute of Ahli Sunnah Wal Jama'ah, Faculty of Science, Technology and Human Development, Universiti Tun Hussein Onn Malaysia (UTHM), \\ Parit Raja 86400 Batu PahatJohor Darul Takzim, Malaysia \\ *Corresponding author: zahari@uthm.edu.my
}

\begin{abstract}
The missing person issue has recently become the issue of the world, especially after the Malaysian Airlines MH370 tragedy a few years ago. In Islam, the missing person is known as 'Al-Mafqud'. One of the largest issue is how the management of missing person's properties which can also affect country and their heirs. Management of missing person's properties is different as compared to management of inheritance properties. Uncertain status of person's life or death creates the conflict and their property needs to be frozen due to law constraints either in Malaysia civil or syariah law. This phenomenon raises many issues and problems that become increasingly critical and extremely difficult to resolve. Besides, if the muslim's properties do not develop, it can cause detrimental effect to the muslim community. In Islam, the wastage of wealth resource is highly discouraged because it will cause significant impact to the Muslims. Moreover, if the property is used wisely, it will give a positive impact to the society, economy and education. On that matter, in 1982 National Fatwa Committee has already given the decree that the government has the right to acquire or use any form of property that is not used for public interest. But until now, no effective measures have been taken by the government to ensure that these issues can be dealt with properly. Hence, this research addresses the management of missing person's properties in the Maqasid Syariah dimensions.
\end{abstract}

Keywords: Missing person; estate management; legal issue; maqasid syariah

(C) 2017 Penerbit UTM Press. All rights reserved

\subsection{INTRODUCTION}

Wealth is a trust by Allah S.W.T given to humans as a symbol of blessing in the world. Human received the wealth from God and it is a right to use it and disburse to the beneficiary through an organized way by Syarak. Thus, the administration and management of property in Islam are emphasized with reference to the established concept and rules or laws [1]. The wealth is a temporary gift from Allah S.W.T as an award to achieve a blessed life. In Islam different categories of wealth are Mutaqawwan, Ghair Mutaqayyam, Mithy, Qimmi, Manqul, Ghair Manqul, Istikhali and Istiklak [2]. The property included in Ghair Manqul categories. The concept covers all the things that exist on the surface of the earth, such as buildings, water, vegetation and mineral resources that exist under it. Property in Islam has its own unique concept. There are various opinions, estimates and opinions concerning to this property according to Muslim scholars. However, despite the different aspects of assessment, goals and purpose are still the same. There are two key features in determining property in Islam [3];

i. An object that can be stored or collected and can be used as a right.

ii. Objects that can be taken advantage and benefit.

\subsection{THEORETICAL OF THE STUDY}

\section{Maqasid Syariah}

Maqasid is an Arabic word which carries the meaning of goals or purposes and when it refers to Shariah it specifically means the goals and purposes of Shariah. There are three other Arabic words that are found in the relevant literatures of usul al-figh that convey similar meaning as maqasid. These words are hikmah [wisdom], 'illah [effective cause] and maslahah [interest or benefits]. The approach to Maqasid was not given special attention, even many of the reputable text of usul al-fiqh do not even have a section or chapter to the study of maqasid, until Maqasid al-Shariah given a special emphasis [4]. Most Muslim scholars are of the opinion that the ultimate objectives 
[maqasid al-Sariah] which are a necessity [al-daruriyyah] for mankind to be able to live peacefully in this world, according to al-Quran and al-Sunnah, include five main areas shown in Figure 1 below [4].

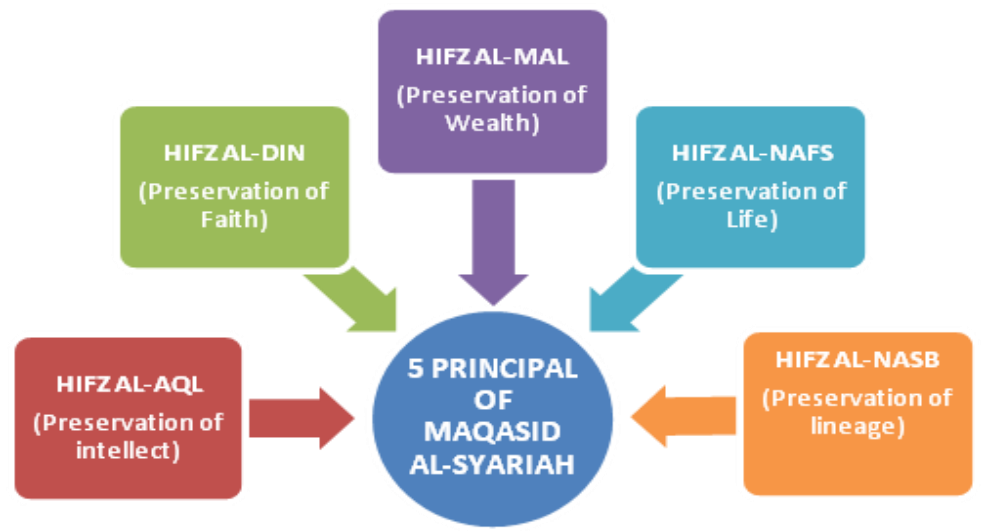

Figure 1 Element of maqasid syariah

Protection of wealth (Hifz al-mal) is one of the requirements of human life and human beings will not separate from it. Islam does not prevent the human search for treasure as much as it is affordable and does not violate Islamic law. This is consistent with human nature to maintain the property in order to increase the degree and the pleasures of the world. However, in fact all wealth belongs to Allah, but Islam also recognizes the right of a private person [4].

Therefore man is obsessed with wealth, and working through the various roads set by Islam to avoid chaos within each other. Nowadays, there are plenty of opportunities for one to engage in permissible business activities, be it small proprietary businesses up to the level of corporations. Besides creating wealth via direct engagement with businesses, wealth can also be created when one invests in Syariah compliant instruments that are offered in one's country such as investing in stocks, unit trusts, Sukuk or investing in investment accounts approved by the respective Syariah advisory councils.

Besides that, the Quran and Sunnah have also elaborated on the importance of wealth creation in Islam by setting the parameters on the responsibility of those who have adequate means to help those who are less fortunate. This can be observed through the encouragement to give hibah (gifts), alms and to give out the obligatory zakat to the rightful recipients which have been outlined by the Syariah law. The Quran has also stated the important principles in managing the wealth of a country whereby the responsible parties are required to ensure that its wealth is justly distributed among the citizens. To further emphasise on the importance of the wealth creation, Allah has explicitly prohibited the act of hoarding and monopolizing the wealth of a nation in a way that will deny the needy of their rights to the wealth.

\subsection{MEANING OF AL-MAFQUD AND CONCEPT}

Al-Mafqud is defined as someone who are lost from place in a long period without news and no one knows about him and is also unknown whether he is still alive or had pass away [5]. In another reference Al-Mafqud is defined as someone who is lost from some place without any news and his status is unknown [6].

According to the Estates of Missing persons Act 1996 of Canada, gave a definition of a missing person is a person who lives in a place where relatives of the person who knows it, and you might hear the news, it was already unable to hear any news from him that at least 3 last month,[7]. Whereas according to the Estates of Missing persons Act (management) 1973 Uganda stated purpose of being a person who disappeared without making reasonable provision for the administration of his property. if any, and they disappeared without the news in the last six months, any relative of a missing person may, with the consent of the family, ask the court to issue commands to manage the property, but the court may, if it deems necessary or desirable, giving orders to more than a heirs to manage the property together [8].

\section{Period to Wait for Al-Mafqud for Presume of Death}

There is difference of definition from scholar regarding the period for Al-Mafqud to be declared as dead or known as presumption of death [9]. Basically, the period of someone missing or disappeared as the main consideration. The scholars have different opinion of about waiting period of al-mafqud. Imam Hanafi had determination of period should depend on the peer of Al-Mafqud. When peers of AlMafqud no longer exist, then the confirmation of the death can be declared. He believes that because during his time, most of the people died around the age of 120 years. Imam Al-Maliki give opinion Al-Mafqud can be considered dead when their ages reach the age around 70 to 80 years old. Imam Syafie's opinion said, the missing person will be presumed dead when his entire peer had already gone, whereas in terms of age, he/she must past 90 years old. Meanwhile, Imam Hambali said, a person is found to be missing in a situation, where the situation was destroyed, like those lost in the war, sailing or in the plane that crashed, then it should be investigated for four years and if one is lost in a condition that is not the case of destruction, like those who go to trade or travel, or study. So it is in this state, there are two opinions either Wait until the 90 years since it was born or based to Ijtihad (decision) of Judge. 
Property Management of Al-Mafqud

Unclear status of death can create a conflict, especially in the issues related to inheritance of Al-Mafqud property to the heirs. Civil and Syariah law barrier have a significant impact [10]. This is because basically, Al-Mafqud belongings cannot be claimed by the relatives until a confirmation about the status of death is determined by the court. Due to the problem, new efforts are required to solve the real estate of Al-Mafqud issue. In an effort to resolve issues related to real estate of Al-Mafqud, a declaration of presumption of death must be obtained in advance from the court. However, Malaysia has a legal system, Syariah Law and Civil Law, which states that any legislation should not ultra-vires [11]. However, in terms of implementation and understanding of the community there is a challenge in order to develop the Al-Mafqud property. Syariah court judge's decision only affects the dissolution of his marriage and not succession, although the waiting period is just 4 years. The presumption of death issued by the Syariah courts is only received by the Office of the Registrar of Marriages and Divorces in the states, but does not mean the division of inheritance [12]. For the purposes of inheritance, the Presumption of Death issued by civil high court is required [19]. According to the Civil law, which stipulates that a person can be considered dead when there is no any news heard from him for seven years by those who would normally have heard of him. However, through the civil legislation, still have a chance for the acquired property temporarily by the government and the heirs, via High Court orders [13]. But it is rarely practiced because there is no specific law in this case, besides it's very costly.

\subsection{RESULTS AND DISCUSSION}

\section{Issues in the Property Management of Al-Mafqud}

On the issue of ownership before somebody is Al-Mafqud, or property acquired during his disappearance, the property cannot be distributed among the heir or nominated until there is death confirmation such as a death certificate or court declaration after certain period. The period is not fixed, but will depend on the judge to confirm his death. Before probate any property transaction is illegal because the Al-Mafqud is still assumed alive. The property cannot also be inherited wealth, but convincingly. After the judge confirmed his death his property passes to the persons entitled to receive it.

\section{i. Inheritance of Al-Mafqud's Property.}

Inheritance means pertaining to the legal heirs or the estate and inheritance [14]. While the heir are the party entitled to receive an inheritance from a person who had died. In the inheritance of Al-Mafqud problem, there are two conditions, namely [14];

Al-Mafqud as people who inherit property (muwaris).

After the court issues an order for the presumption of death of Al-Mafqud, the property can be inherited by their families in accordance with the command of Allah in the Qur'an. However, before the property can be distributed to those who are nominated, something should be done by the heirs in advance, the rights related to the estate is divided into five (5) areas namely;

- The rights to the goods,

- The right to prepare the funeral cost of the deceased,

- $\quad$ The right to settle the debt.

- Execute a will.

- Distribute the remaining inheritance to the heirs of the right according to the position

\section{ii. Al-Mafqud as Heirs Will Inherit The Property.}

Al-Mafqud will still be considered alive as long as there is no evidence, or prove of his death or until the judge does not confirm his death. Based on this principle he was entitled to inherit until there is confirmation and if there are heirs who will not receive an inheritance in one assumption, this heir cannot inherit the estate because there is a possibility that the missing are still alive. This means, if any heir AlMafqud died and left behind a number of properties he lost during the period, missing persons still has the right to inherit property. In this case, it will cause a severe crisis, as long as the status is not decided by the court, the other heirs cannot claim.

\section{iii. The Legal Issue of Al-Mafqud.}

The legal system in Malaysia is divided into two, namely Syariah and Civil law. Each law, not just have different period for presumed of death, but also have different functions.

\section{Civil Law}

Regarding the section 108, Evident Act 1950, the period for Al-Mafqud can presume as dead is 7 years and can be declared by the Civil High Court and above. Only the presumed of death or Death Declaration from Civil court can be used by the heirs in the claim process of inherence property [15]. 


\section{Syariah Law}

Syariah law is under the state government's authority. All states in Malaysia (except Terengganu) in Syariah law stated the waiting period for a presumption of death is 4 years. However, the function of presumption of death ruled by the Syariah Court is for resolving matters relating to the dissolution of marriage, such as a wife of Al-Mafqud wanting to remarry, but not for property claims.

Article 121 (1A) of the Federal Constitution states the Civil Court cannot 'ultra vires" about Syariah Court [10]. Amendment of Article 121 of the Constitution in 1988 showed that the existence and integrity of Syariah law has been recognized by the Federal Constitution and the Syariah Court now has the absolute power to decide and resolve cases or some things that are under its jurisdiction. This means that the civil court can no longer talk about a case that is under the jurisdiction of the Syariah Court.

This change is made because there are some cases in which the civil court had previously discussed cases even though the basic thing in those case is under the jurisdiction of the Syariah Court. Thus, these changes are expected to be the solution to disagreements which arise and clarify the division of jurisdiction between the two courts. The amendments have given special status to the Syariah Court. The greatest effect is obtained with this change, the conflict between Syariah and civil court's decisions can be avoided.

As it happened in some previous cases involving custody of children cases, matrimonial property, and so illegitimate child at the Civil High Court, which is not in favor of Islamic law so that the parties are Muslims feel it is harmful. On the other hand, the Civil High Court decision in favor of the law contrary to Islamic law. Civil courts have also made decisions on matters within the jurisdiction of the Syariah Court and sometimes have to change a decision made by the Syariah court.

With this amendment the difference between the Civil Court and Syariah Court will not occur again because the matter can only be brought to the Syariah and Civil courts no longer have jurisdiction. Therefore, this problem can be solved. The jurisdiction of the two courts, each run as the track is in the constitution and will not at all extreme power.

Syariah law is a law that was revealed by Allah SWT that is complete and become a guide for human being. The differences between other legal systems and Islamic Syariah law is the Islamic law is derived from the Quran and Sunnah, the real revelation and revelation implied to all of humanity [14]. Overall, people are collectively responsible for dispensing justice. Syariah law is not the same as the existing law and practice, and also not the same as the British Common Law resulting from the writ [14].

\section{Benefit the Property Management of Al-Mafqud}

A number of advantages can be achieved when the Al-Mafqud property can be used for the society and also the development of the nation. Since the large value of property can be managed properly and wisely. Without the proper strategy for property management of AlMafqud, it will lead to high loss for the country. Following are the advantages that can be considered to be applied for Al-Mafqud property:

\section{- Poverty}

A majority of the indigent consists of Muslims themselves. This group looks so weak that it leads to it the other problems such as social issues, education and poverty. Property owned by Al-Mafqud can be developed to eradicate poverty among Muslims. Payment of zakat from Al-Mafqud property and the involvement of the indigent in developing property of Al-Mafqud will create a harmonious society.

- Education.

The formation of human capital in Islamic societies is crucial to ensure continuity and sustainability of the Islam. Various programs such as scholarships, establishment of religious schools, the construction of the universities and short courses can be implemented if the property of Al-Mafqud can be defrosted and used towards the better development of human capital.

\section{- Economy}

The economic power of the Muslim community does not describe as it should be despite being a majority in Malaysia. Equity holdings in company shares and the Muslim community is still weak. Economic empowerment of Muslims is crucial and with the existence of proper management of Al-Mafqud property, it will provide better opportunities.

\subsection{CONCLUSION}

Undeclared status of Al-Mafqud affects the property distribution to the heirs and unclaimed property due the status of Al-Mafqud can be use full if the property can be utilized for society especially for development of Islamic society. The advantage management of Al-Mafqud property also have been presented which can provide benefit to elevate poverty, education and the economy. Moreover, the property management of Al-Mafqud properties can be introduced in order to effectively utilize the property. The government should play a major role as well as draft a special law on Al-Mafqud property management as already done in a few countries in the world and the maqasid syariah can be use as the principle for develop new solution to bring up the best solution on the al-Mafqud's property.

\section{References}

Abd al-Karim al-Khatib. (1976). Al-Siyasah Al-Maliyah Fi Al-Islam Wa Al Mucamalah Silatuha Bi Wa Al-Mucasarah. Cairo: Dar al Fikr.

Abdul Rashid et al. (2013). Property Management Through Grants: The Importance And Benefits Of Various Aspects for the Development of Ummah. Jurnal Hadhari, 5(1), 91-104.

Ibrahim, L. (2006). Al-Mafqud Real Problems According to Shariah law in the Malaysian Perspective. (PhD Thesis). State Islamic University Pekan Baru, Indonesia.

Mohamed, H. A. H. (2014). Presumption of Death Al-Mafqud Accordance with the Civil and Syariah Law: An Evaluation Time- Canon Journal of Language and Literature. Retreived June 2014 from the World Wide Web:http://jurnalkanun.dbp.my/wordpress/?p=1019. 
Mohd Zamro, M. A. and Ridzuan, M. (2006). Islamic Inheritance Law Implementation in Malaysia, Bangi: Shariah Department. Faculty of Islamic Studies, Universiti Kebangsaan Malaysia.

Muhammad Ali Ash-Shabuni. (1996). Allocation According to Waris Islam. Sooriya Printing.

Amir Bahari. (2012). Q Will Islam. The National Library of Malaysia. Telaga Biru. Ltd.

Muhammad bin Ibrahim bin Abdullah At Tuwaijry (2007), Law Of Inheritance Guidance J. Book Da'wah And Aliyat College Rabwah, 25.

Mustafa al-Khan, et al. (2005). Fiqhul Manhaji Volume 2. Damascus, Syria: Printing Darul Qalam.

The Commissioner of Law Division, Malaysia. (2006). Section 108 of the Evidence Act 1950 (revised 1971).

Shaykh Muhammad al-Tahir Ibn Ashur. (2006). Maqasid al-Sharia al-Islamiah, Tunis: Dar al-Islam.

Syariah Judiciary Department Malaysia. (2013). Malaysia Syariah Judicial Department Report for Year of 2013.

Syed Iskandar Syed Jaafar Al-Mahdzar. (2015). Legal Issues Relating MH370. The Malaysian Insider

The Federal Constitution of Malaysia. (1988). Article 121 (1A) of the Federal Constitution.

Wahbah al Zuhaili. (1996). Fiqh and Islamic Jurisprudence Volume 1V, translated by End Yaacob Md at.al and Original Book al-Fiqh al-islamiwa Adillatuhu al-Jul al Thani. Kuala Lumpur: Dewan Bahasa Pustaka.

Wahbah al-Zuhaili. (1984). Fiqh al Islami waa Dillatuhu. Damsyik: Dar al Fikr.

Wan Abdul Halim (2009). Inheritance Property Management. PTS. 